\title{
Detection of fusidic acid resistance determinants among Staphylococcus aureus isolates causing skin and soft tissue infections from a tertiary care centre in Chennai, South India
}

\author{
A Nagarajan ${ }^{1 *}$, K Arunkumar $^{2}$, M Saravanan ${ }^{1}$, G Sivakumar ${ }^{2}$, Padma Krishnan $^{1}$ \\ From First International Science Symposium on HIV and Infectious Diseases (HIV SCIENCE 2012) \\ Chennai, India. 20-22 January 2012
}

\section{Background}

Fusidic acid (FA)- an inhibitor of protein synthesis has been used for treating superficial and some systemic infections caused by Staphylococcus aureus. Fusidic acid resistance in $S$. aureus has been reported throughout the world with prevalence ranging from $0.5 \%$ to $50 \%$ and is due to i) point mutation in bacterial fusA or fusE gene and ii) by acquired FA resistance determinants fus $B, C$ and $D$. Indian report of fusidic acid resistant $S$. aureus (FRSA) is based on phenotypic detection. Hence, this study was done to detect acquired FA resistance determinants.

\section{Methods}

The study included 54 isolates of $S$. aureus collected from skin infections between Jan to Mar 2011 from a tertiary hospital in Chennai. MRSA was screened by cefoxitin disc diffusion method and PVL-MRSA detection was done by multiplex-PCR. FA resistance was screened by disc diffusion method and acquired resistance determinants were detected by multiplex-PCR.

\section{Results}

Of the 54 S. aureus isolates, 32(59.2\%) were found to be MRSA. A total of $13(24.1 \%)$ isolates were found to carry $p v l$ gene of which 4 were MRSA. Two of the 54(3.7\%) isolates were found to be FRSA and harbored fusC gene. Both FRSA isolates were from non-hospitalized patients and they were using FA for topical treatment.

\footnotetext{
* Correspondence: nagaibms@gmail.com

'Dept. of Microbiology, Dr. ALM PG Institute of Basic Medical Sciences,

University of Madras, Chennai-600113, India

Full list of author information is available at the end of the article
}

\section{Conclusion}

We report for the first time in India the presence of acquired FA resistant determinant fus $\mathrm{C}$ gene in community isolate of methicillin susceptible $S$. aureus. Indiscriminate use of FA needs to be avoided to prevent the emergence of FRSA.

\section{Author details}

'Dept. of Microbiology, Dr. ALM PG Institute of Basic Medical Sciences, University of Madras, Chennai-600113, India. ${ }^{2}$ Rajiv Gandhi Govt. General Hospital and Madras Medical College, Chennai-600003, India.

Published: 4 May 2012

\section{doi:10.1186/1471-2334-12-S1-P45}

Cite this article as: Nagarajan et al:: Detection of fusidic acid resistance determinants among Staphylococcus aureus isolates causing skin and soft tissue infections from a tertiary care centre in Chennai, South India. BMC Infectious Diseases 2012 12(Suppl 1):P45.

Submit your next manuscript to BioMed Central and take full advantage of:

- Convenient online submission

- Thorough peer review

- No space constraints or color figure charges

- Immediate publication on acceptance

- Inclusion in PubMed, CAS, Scopus and Google Scholar

- Research which is freely available for redistribution 